\title{
Determination of carboxyhaemoglobin and methaemoglobin levels in donated blood
}

\author{
Determinação dos níveis de carboxihemoglobina e metahemoglobina no sangue doado \\ Determinación de los niveles de carboxhemoglobina y metahemoglobina en sangre donada
}

Received 07/29/2021 | Reviewed: 08/04/2021 | Accept: 08/06/2021 | Published: 08/11/2021

\author{
Alessandra Cristina Pupin Silvério \\ ORCID: https://orcid.org/0000-0003-2093-2713 \\ Universidade José do Rosário Vellano, Brazil \\ E-mail: alessandrapupin72@gmail.com \\ Simone Caetani Machado \\ ORCID: https://orcid.org/0000-0002-3440-7162 \\ Universidade Federal de Alfenas, Brazil \\ E-mail: simonecaetani@uol.com.br \\ Vanessa Caroline Cardoso Silva \\ ORCID: https://orcid.org/0000-0002-2694-6385 \\ Universidade José do Rosário Vellano, Brazil \\ E-mail: vanessacardoso9902@ hotmail.com \\ Estéfane Rodrigues \\ ORCID: https://orcid.org/0000-0002-3894-6972 \\ Universidade José do Rosário Vellano, Brazil \\ E-mail: estefanerodrigues15@yahoo.com.br \\ Isarita Martins \\ ORCID: https://orcid.org/0000-0001-7471-3773 \\ Universidade Federal de Alfenas, Brazil \\ E-mail: isarita.sakakibara@unifal-mg.edu.br
}

\begin{abstract}
To determine the percentages of carboxyhaemoglobin $(\mathrm{COHb})$ and methaemoglobin $(\mathrm{MeHb})$ in donor blood and to compare these levels between smokers and nonsmokers at different time points during blood storage. Blood donors were recruited from Haematology Service, University Hospital Alzira Velano, Alfenas-MG. The blood was kept in collecting ducts (noodles) containing citrate, phosphate and dextrose (CPD) and stored at $4{ }^{\circ} \mathrm{C}$ throughout the storage period. Since the noodles kept the characteristics of the bags, $\mathrm{COHb}$ and $\mathrm{MeHb}$ levels were analysed on the day of donation and after 20 days of storage. Levels of $\mathrm{COHb}$ and $\mathrm{MeHb}$ were determined using spectrophotometric methods. Non-parametric Friedman and Mann-Whitney tests were employed to compare $\mathrm{COHb}$ and $\mathrm{MeHb}$ levels before and after the storage and groups of smokers and nonsmokers, respectively. Levels of $\mathrm{COHb}$ and $\mathrm{MeHb}$ in the blood collected from smokers and nonsmokers were statistically different $(p<0.05$; Mann- Whitney test) when the samples were analyzed before the storage. In blood of smokers, $\mathrm{COHb}$ levels were no different over a 20-day storage period ( $p=0.7009$; Friedman test). On the other hand, MeHb levels were significant different over a 20-day storage period $(p<0.05)$. The results suggest the need to regularly assess $\mathrm{COHb}$ and $\mathrm{MeHb}$ levels in donor blood stored in blood banks.
\end{abstract}

Keywords: Blood bag; Carboxyhaemoglobin; Methaemoglobin; Storage period.

\section{Resumo}

Determinar as porcentagens de carboxihemoglobina $(\mathrm{COHb})$ e metahemoglobina $(\mathrm{MeHb})$ no sangue de doadores e comparar esses níveis entre fumantes e não fumantes em diferentes momentos durante o armazenamento de sangue. Os doadores de sangue foram recrutados no Serviço de Hematologia do Hospital Universitário Alzira Velano, Alfenas-MG. O sangue foi mantido em dutos coletores (macarrão) contendo citrato, fosfato e dextrose (CPD) e armazenado a $4{ }^{\circ} \mathrm{C}$ durante todo o período de armazenamento. Como o macarrão manteve as características das sacolas, os níveis de $\mathrm{COHb}$ e MeHb foram analisados no dia da doação e após 20 dias de armazenamento. Os níveis $\mathrm{de} \mathrm{COHb}$ e $\mathrm{MeHb}$ foram determinados usando métodos espectrofotométricos. Os testes não paramétricos de Friedman e Mann-Whitney foram empregados para comparar os níveis de $\mathrm{COHb}$ e $\mathrm{MeHb}$ antes e após o armazenamento e grupos de fumantes e não fumantes, respectivamente. Os níveis de $\mathrm{COHb}$ e $\mathrm{MeHb}$ no sangue coletado de fumantes e não fumantes foram estatisticamente diferentes ( $\mathrm{p}<0,05$; teste de Mann-Whitney) quando as amostras foram analisadas antes do armazenamento. No sangue de fumantes, os níveis de $\mathrm{COHb}$ não foram diferentes ao longo de um período de armazenamento de 20 dias ( $\mathrm{p}=0,7009$; teste de Friedman). Por outro lado, os níveis de MeHb foram significativamente diferentes ao longo de um período de armazenamento de 20 dias $(\mathrm{p}<0,05)$. Os resultados sugerem a necessidade de avaliar regularmente os níveis de $\mathrm{COHb}$ e $\mathrm{MeHb}$ no sangue de doadores armazenado em bancos de sangue. 
Palavras-chave: Bolsa de sangue; Carboxihemoglobina; Metahemoglobina; Período de armazenamento.

\section{Resumen}

Determine los porcentajes de carboxihemoglobina $(\mathrm{COHb})$ y metahemoglobina $(\mathrm{MeHb})$ en la sangre de los donantes y compare estos niveles entre fumadores y no fumadores en diferentes momentos durante el almacenamiento de sangre. Los donantes de sangre fueron reclutados en el Servicio de Hematología del Hospital Universitario Alzira Velano, Alfenas-MG. La sangre se mantuvo en conductos colectores (macarrones) que contenían citrato, fosfato y dextrosa (CPD) y se almacenó a $4{ }^{\circ} \mathrm{C}$ durante todo el período de almacenamiento. Como los fideos mantuvieron las características de las bolsas, se analizaron los niveles de $\mathrm{COHb}$ y MeHb el día de la donación y después de 20 días de almacenamiento. Los niveles de $\mathrm{COHb}$ y $\mathrm{MeHb}$ se determinaron mediante métodos espectrofotométricos. Se utilizaron pruebas no paramétricas de Friedman y Mann-Whitney para comparar los niveles de $\mathrm{COHb}$ y MeHb antes y después del almacenamiento y los grupos de fumadores y no fumadores, respectivamente. Los niveles de $\mathrm{COHb}$ y $\mathrm{MeHb}$ en sangre extraída de fumadores y no fumadores fueron estadísticamente diferentes ( $\mathrm{p}<0,05$; prueba de MannWhitney) cuando las muestras se analizaron antes del almacenamiento. En la sangre de los fumadores, los niveles de $\mathrm{COHb}$ no fueron diferentes durante un período de almacenamiento de 20 días ( $\mathrm{p}=0,7009$; prueba de Friedman). Por otro lado, los niveles de $\mathrm{MeHb}$ fueron significativamente diferentes durante un período de almacenamiento de 20 días ( $\mathrm{p}<0,05)$. Los resultados sugieren la necesidad de evaluar periódicamente los niveles de $\mathrm{COHb}$ y $\mathrm{MeHb}$ en sangre de donantes almacenada en bancos de sangre.

Palabras clave: Bolsa de sangre; Carboxihemoglobina; Metahemoglobina; Periodo de almacenamiento.

\section{Introduction}

Tobacco smoking is an important etiologic factor in several potentially deadly diseases, including ischemic heart disease and cancer. Potentially toxic substances such as carboxyhaemoglobin $(\mathrm{COHb})$ and methaemoglobin $(\mathrm{MeHb})$ are found at elevated levels in smokers, and these substances cause a blockade of $\mathrm{O}_{2}$ transport that can lead to ischemia, tissue necrosis and heart failure (Madany, 1992; Scaff et al., 2020).

$\mathrm{COHb}$, an adduct of haemoglobin and carbon monoxide $(\mathrm{CO})$, is endogenously formed in the body and found in the blood, especially after exposure to exogenous CO (Bachelet et al., 2002; Czogała et al., 2006; Maestrelli et al., 2001; Mao et al., 2021; Scaff et al., 2020; Smithline et al., 2003; Westphal et al., 2003). After the COHb adduct is formed, the ability to transport $\mathrm{O}_{2}$ from the blood decreases, causing tissue hypoxia. The dissociation curve of oxyhaemoglobin is moved to the left in the presence of $\mathrm{COHb}$, further reducing the amount of $\mathrm{O}_{2}$ delivered to the tissue. Tissue hypoxia occurs with $\mathrm{CO}$ poisoning, with readily apparent effects in the brain and the heart (Ehlers et al., 2009). The level of COHb in the blood is commonly treated as the best and most integral marker of human exposure to environmental $\mathrm{CO}$ and exposure to $\mathrm{CO}$ emitted by the incomplete combustion of tobacco (Czogała et al., 2006; Ehlers et al., 2009; Madany, 1992). COHb is typically found in the blood at levels of $0.4 \%$ to $1.0 \%$, but it reaches levels of up to $15 \%$ in smokers (Czogała et al., 2006; Spada et al., 2006).

Transfusion of blood and blood components, such as red blood cells (RBC), platelets, plasma, and cryoprecipitate are one of the most common medical procedures performed in the developed world. No medical intervention is without risks, but in principle, these risks should be offset or justified by immediate or long-term benefits (Szczepiorkowski \& Dunbar, 2013). Collecting the appropriate quantity and quality of blood is challenging (Spada et al., 2006).

Levels of $\mathrm{COHb}$ and methaemoglobin $(\mathrm{MeHb})$ in donor blood have not been well explored, but these compounds present a potential risk to transfusion recipients (Uchida et al., 1990). Aronow et al. (1984); Ehlers et al. (2009); Uchida et al. (1990) have reported that increased levels of COHb in transfusion blood pose a potential risk factor for impairment of cardiovascular function. This risk is particularly concerning for critically ill patients who must undergo a massive blood transfusion, such as patients with heart or pulmonary disease, and for paediatric patients undergoing cardiac surgery. Increased levels of $\mathrm{MeHb}$ diminish the capacity of donated blood to integrate into a recipient, and $\mathrm{O}_{2}$ transport in haemoglobin can also potentially cause hypoxemia in such patients (Mao et al., 2021; Uchida et al., 1990).

In addition to the presence of $\mathrm{COHb}$ and $\mathrm{MeHb}$ in donor blood from smokers, it should be noted that the levels of these compounds change during blood storage, potentially further increasing the risk to the receiver. The duration of blood 
storage is directly related to the magnitude of such changes, a trend revealed by Rajashekharaiah et al. (2012). Several irreversible events can occur in erythrocytes, changing their cellular form and composition. These events include fragmentation and aggregation of proteins and lipids as well as the generation of free radicals due to oxidative stress. Free radical species can lead to increased formation of MeHb. Thus, storage can lead to changes in haemoglobin level as well as the oxidative state of erythrocytes (Rajashekharaiah et al., 2012).

The aim of this study was to determine the percentages of $\mathrm{COHb}$ and $\mathrm{MeHb}$ in bags of donor blood collected from smokers and nonsmokers at different time points during storage.

\section{Materials and Methods}

The study is a randomized experimental study of qualitative and quantitative nature. Introducing two groups, one control and the other study group.

The study was conducted in the southern region of Minas Gerais between June and July 2015. Blood donors were recruited (smokers, $\mathrm{n}=61$; nonsmokers=12 (control group)) from Haematology Service, University Hospital Alzira Velano, Alfenas-MG. The research subjects were aged between 18 and 60 years and health compatible with blood donors, where interfering in the levels of $\mathrm{COHb}$ and $\mathrm{MeHb}$ were excluded, such as hemoglobin decrease. Only samples from approved donors (i.e., after clinical and haematological screening) were analysed. The blood was kept in collecting ducts (noodles) containing citrate, phosphate and dextrose (CPD) and stored at $4{ }^{\circ} \mathrm{C}$ throughout the storage period. Since the noodles kept the characteristics of the bags, $\mathrm{COHb}$ and $\mathrm{MeHb}$ levels were analysed on the day of donation and after 20 days of storage. The minimal interval between smoking and donation was 15 minutes. This study was approved by the Brazilian National Committee on Research Ethics - CONEP, n 224/2009.

In addition, each study volunteer completed a questionnaire to gather demographic data (age, gender, etc.) as well as information on lifestyle (smoking, coffee and alcohol consumption, diet, etc.) and occupation (number of working hours per day, number of days worked per year, and personal protective equipment). All samples and data were subjected to blinded analysis. To answer the questionnaire, the volunteer was accommodated in a reserved place and was guided by a trained researcher

Levels of $\mathrm{COHb}$ and $\mathrm{MeHb}$ were determined using spectrophotometric methods according to Evelyn \& Malloy (1938) and Beutler \& West (1984) and modified from Carrazza et al. (2000), validated in the laboratory.

Non-parametric Friedman and Mann-Whitney tests were employed to compare $\mathrm{COHb}$ and MeHb levels before and after the storage and groups of smokers and nonsmokers, respectively. In both tests, the significance level was set at 5\%. Data analysis was performed using BioStat, version 2009 for Windows (AnalystSoft ${ }^{\circledR}$ ).

\section{Results}

The blood donors ranged in age from 18 to 60 years. In total, $83.6 \%$ of the donors were smokers, $53 \%$ were female and $75 \%$ were Caucasian. Regarding current medication use, $83 \%$ were not currently using medication, and some donors were using anti-inflammatory and antihypertensive drugs. Only $6.7 \%$ of the volunteers were regular blood donors; the remaining 93.3\% were first-time blood donors.

Analysis of $\mathrm{COHb}$ was performed in triplicate and the median \pm standard deviation (SD) was $10.1 \% \pm 5.8$ when the blood of smokers was analyzed after the collection. This deviation was mainly due to the variation in time between the last cigarette smoked and the blood collection. Individuals who smoked unfiltered cigarettes or cigarettes with a straw wrapper had higher blood $\mathrm{COHb}$ values than those who smoked commercial type cigarettes, even when smokers of the former types of 
cigarettes had a shorter duration and frequency of exposure to tobacco smoke. The median \pm SD was $11.2 \% \pm 4.3$ in day 20 of storage.

Friedman test was applied to compare multiple related samples when the percentage of COHb was determined in the day of the donation and after the period of storage (Figure 1). In blood of smokers, no significant difference was observed over a 20-day storage period $(p=0.7009)$.

Figure 1. Multiple comparisons of COHb levels in blood of smokers and nonsmokers, before of storage and over 20-day of storage at $4^{\circ} \mathrm{C}$. The horizontal line in the box represents the median.
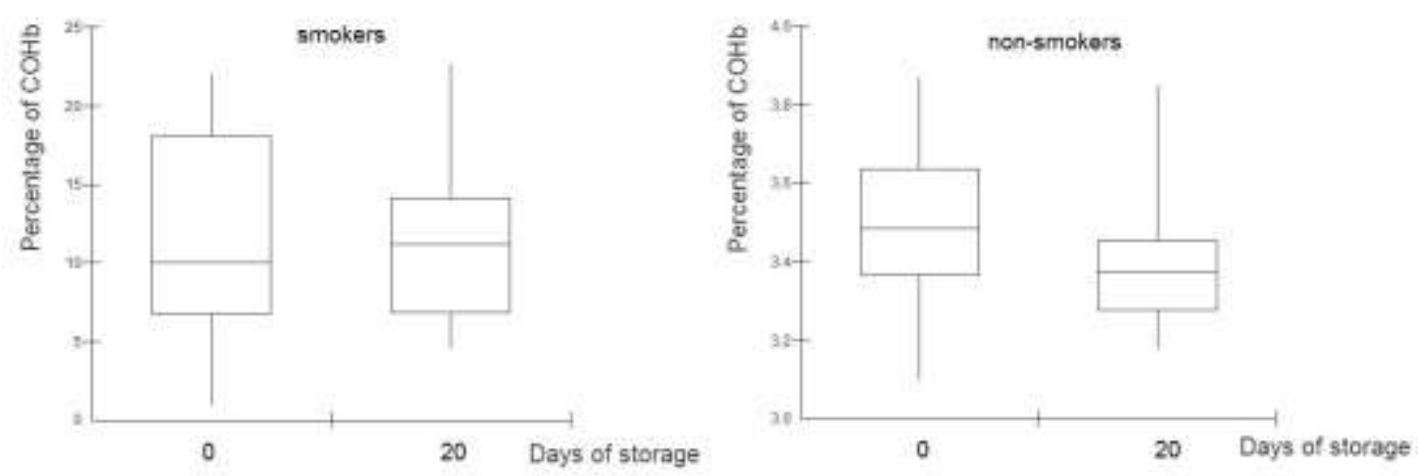

Source: Authors.

Figure 1 shows the percentages of COHB in blood from smokers and non-smokers on the day of collection and after 20 days of storage. We can see through the box plots the variations in the concentrations of COHb between the subjects and the standard deviation. We can still observe that the median of $\mathrm{COHb}$ was high in smokers on the day of blood donation and after 20 days of storage

Median of $\mathrm{COHb} \pm \mathrm{SD}$ was $3.5 \% \pm 0.2$ when the analysis was performed after collection of the blood of nonsmokers. Median of $\mathrm{COHb} \pm \mathrm{SD}$ was $3.8 \% \pm 0.2$ in day 10 of storage and the median of $\mathrm{COHb} \pm \mathrm{SD}$ was $3.4 \% \pm 0.2$ in day 20 of storage (Figure 1). In blood of nonsmokers, no significant difference was observed over a 20-day storage period $(p=0.2482$, Friedman test $)$.

Determination of MeHb was also performed in triplicate and the median \pm SD was $0.5 \% \pm 0.6$, when the blood of smokers was analyzed after the collection. The median \pm SD was $0.7 \% \pm 0.7$ after the storage of the blood over 20 -days. Friedman test was applied to compare these samples (Figure 2). In blood of smokers, significant difference was observed over a 20-day storage period $(p<0.05)$. 
Figure 2. Multiple comparisons of MeHb levels in blood of smokers and nonsmokers, before of storage and over 20-day of storage at $4^{\circ} \mathrm{C}$. The horizontal line in the box represents the median.
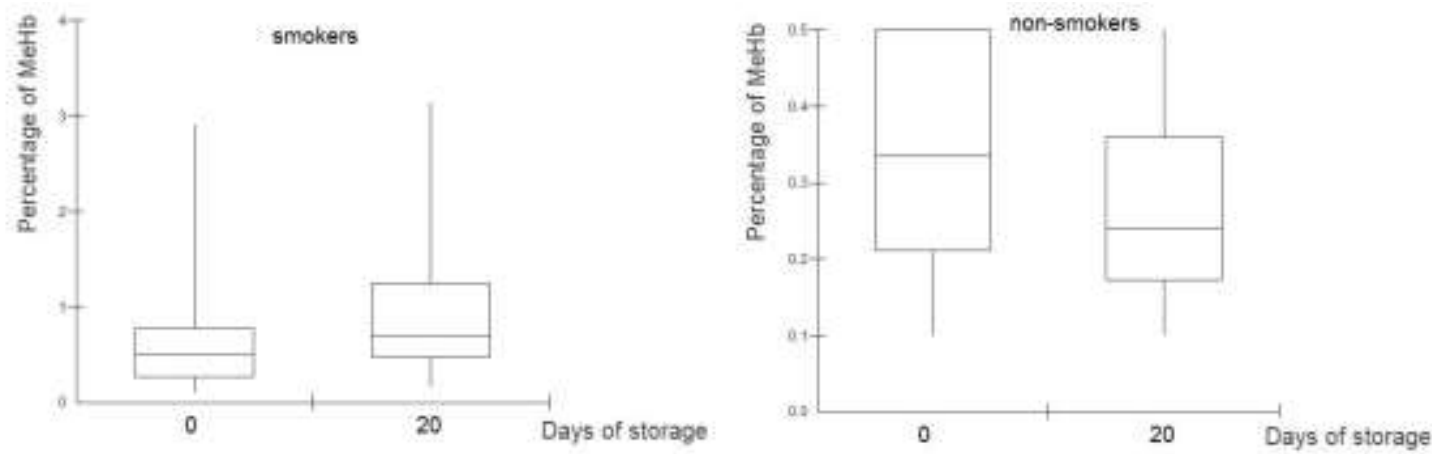

Source: Authors.

Figure 2 shows the percentages of $\mathrm{MeHb}$ in the blood of smokers and non-smokers on the day of collection and after 20 days of storage. We can see through the boxplots the variations in MeHb concentrations between subjects and the standard deviation. We can also observe that the median of MeHb was highest in smokers after 20 days of storage.

Median of $\mathrm{MeHb} \pm \mathrm{SD}$ was $0.3 \% \pm 0.2$ in day 1 , when the analysis was performed after collection of the blood of nonsmokers. Median $\pm \mathrm{SD}$ of MeHb was $0.2 \% \pm 012$ over 20-days of storage. In blood of nonsmokers, no significant difference was observed over a 20-day storage period ( $p=0.2482$, Friedman test).

Before the storage, the levels of $\mathrm{COHb}$ and $\mathrm{MeHb}$ in the blood collected from smokers and non-smokers were statistically different ( $p<0.05$; Mann- Whitney test).

\section{Discussion}

Self-reports of smoking status may not always be reliable and some biomarkers, such as COHb, urinary thiocyanate and plasma thiocyanate from tobacco smokers, can be considered for the evaluation. COHb level is an important indicator of the internal dose of CO (Salles, 2013; Siqueira et al., 1997; Siqueira et al., 1999) to assess occupational and environmental exposure and is used to assess the risk posed by donor blood when performing blood transfusions. In the present study, most donors were smokers and the RBC supply would not be sufficient if that population were excluded.

According to Spada et al. (2006), smokers aged 21-40 years have very high levels of COHb in their blood. In agreement with these results, in the present study, the highest COHb levels were found in blood donated from individuals between 18 and 30 years in age (47\%), which was a disproportionate contribution of donors from the working population. In total, $53 \%$ of the donor group was composed of females, which differs from the proportions in the studies by Madany (1992) and Spada et al. (2006) (the latter of which had only three female donors who smoked). In addition, 75\% of our group of donors who smoked were Caucasian, which is similar to the percentage (77.5\%) in the study by Spada et al. (2006).

The median blood $\mathrm{COHb}$ in the nonsmokers was 3.5\%, which is considered high for this category of exposure, as the reference value for the general population is 1.5\% (Czogała et al., 2006; Spada et al., 2006). This high level of COHb can be attributed to increased exposure to environmental CO due to chemical contaminant exposure. Ramirez et al. (2014) measured $\mathrm{COHb}$ levels in the general population and reported that levels higher than $3.0 \%$ are typically due to more than a single source of CO exposure. Likewise, Czogała et al. (2006) showed an increase of $0.31 \%$ to $2.19 \%$ in non-smokers, which could also be attributed to increased sources of $\mathrm{CO}$ exposure. 
The median of $\mathrm{COHb}$ in the bags of blood collected from the smokers was $10.1 \%$, which is approximately three times higher than the levels found in the blood from the non-smokers. Other authors have also reported increased percentages of COHb in blood donated by smokers (Aronow et al., 1984; Ehlers et al., 2009; Madany, 1992; Uchida et al., 1990; Westphal et al., 2003). According to Ehlers et al. (2009), only bags of blood containing COHb levels equal to or less than $1.5 \%$ can be used for transfusion. Aronow et al. (1984) found that $49 \%$ of donor blood bags have $\mathrm{COHb}$ levels greater than $1.5 \%$, and $2 \%$ of bags have levels greater than $10 \%$. Madany (1992) found that $32 \%$ of donor blood bags from smokers have COHb levels between $5.1 \%$ and $9.1 \%$. Uchida et al. (1990) determined that approximately $2.2 \%$ of donor blood bags have COHb levels greater than 7.5\%, and Ehlers et al. (2009) reported measurements of up to 12\% COHb. Åberg et al. (2009) concluded that bags of RBC stored at blood banks can also have CO levels above the physiologic level in a study conducted in Umeå, Sweden.

The time interval between cigarette smoking and blood donation seems to be a particularly important factor for elevated CO levels. In this study, some donors smoked until 15 minutes before the collection of the blood. The SD in the percentage of $\mathrm{COHb}$ in the donor blood collected from the smokers was high due to variations in the time between the last cigarette smoked and blood collection (15 to 2880 minutes). The half-life of COHb is five and a half hours (Baselt, 1997), and therefore, the time elapsed between the last exposure to tobacco and blood collection strongly influences $\mathrm{COHb}$ levels. Abstinence from cigarettes substantially decreased the levels of biomarkers of tobacco, with levels of $\mathrm{COHb}$ and other compounds being proportional to the length of abstinence, as verified both in this study and in another study reported by Krautter et al. (2015). Higher percentages of $\mathrm{COHb}$ (up to 18\%) were found in individuals who smoked within 3 hours prior to blood collection.

Another important factor in $\mathrm{COHb}$ formation is the type of cigarette smoked. Unfiltered or straw-wrapped cigarettes produce higher blood $\mathrm{COHb}$ levels than commercial type cigarettes, even when the duration and frequency of exposure is shorter.

The levels of $\mathrm{MeHb}$ measured in the bags of donor blood showed statistically significant differences between smokers and non-smokers however they were within the range of acceptable references. Uchida et al. (1990) also found similar values of $\mathrm{MeHb}$ in donor blood bags, with $5.5 \%$ of donors showing possible increases of up to $2.25 \%$. The authors discussed that with regard to the amount of haemoglobin available for oxygen transport, increased levels of MeHb, which has no capacity to bind oxygen, in banked blood would be a potential risk factor for hypoxemia in those patients. Rajashekharaiah et al. (2012) reported that the antioxidant protection used by erythrocytes is stable for at least 2 weeks of storage, which may explain why the blood collected from the smokers showed normal MeHb levels.

Since the haemoglobin measurement is often used to decide the transfusion and there is difference between its levels when smokers and non-smokers are compared, determinations of $\mathrm{COHb}$ and $\mathrm{MeHb}$ are important tools in blood banks. Milman \& Pedersen (2009) demonstrated that smokers had consistently higher haemoglobin levels than non-smokers Male smokers had significantly higher mean haemoglobin than non-smokers, being $0.12 \mathrm{mmol} / \mathrm{L}(1.9 \mathrm{~g} / \mathrm{L})$ higher and female smokers had similar haemoglobin as non-smokers. 40-, 50-, and 60-year-old smokers had significantly higher mean haemoglobin than non-smokers, being $0.19-0.27 \mathrm{mmol} / \mathrm{L}(3.1-4.4 \mathrm{~g} / \mathrm{L})$ higher.

\section{Conclusions}

The results obtained in this study suggest the need to regularly assess $\mathrm{COHb}$ and MeHb levels in donor blood stored in blood transfusion services. Other studies must be conducted to verify the variations of $\mathrm{COHb}$ and $\mathrm{MeHb}$ in the blood of smokers so that blood transfusions are better performed. Studies in patients transfused with blood from smokers should be conducted to look at the effects of increased levels of $\mathrm{COHb}$ and $\mathrm{MeHb}$. 


\section{Acknowledgements}

The authors are thankful to the Foundation for the Support of Research of Minas Gerais (FAPEMIG) (scholarship granted to F.A.P. Souza) and staff at Haematology Service, University Hospital Alzira Velano, Alfenas-MG.

\section{Conflict of interest}

The authors have no competing interests.

\section{Author contributions}

A.C.P.S and I.M conceived and planned the study. F.A.P.S. and S.C.M analysed the data. All authors contributed to manuscript preparation.

\section{References}

Åberg, A. M., Sojka, B. N., Winsö, O., Abrahamsson, P., Johansson, G., \& Larsson, J. E. (2009). Carbon monoxide concentration in donated blood: Relation to cigarette smoking and other sources. Transfusion, 49(2), 347-353. https://doi.org/10.1111/j.1537-2995.2008.01951.x

Aronow, W. S., O’Donohue, W. J., Freygang, J., \& Sketch, M. H. (1984). Carboxyhemoglobin levels in banked blood. Chest, 85(5), 694-695. https://doi.org/10.1378/chest.85.5.694

Bachelet, M., Marchand, F., Souil, E., Weyer, A., \& Polla, B. S. (2002). Expression and localization of heat shock proteins in rat basophilic leukemia cells : differential modulation by degranulation , thermal or oxidative stress. Allergy, 57, 791-797. https://doi.org/10.1034/j.1398-9995.2002.23665.x

Baselt R.C. (1997). Biological monitoring methods for industrial chemical. 3rd ed. Foster City: Biomedical Publications.

Beutler, E., \& West, C. (1984). Simplified determination of carboxyhemoglobin. Clinical Chemistry, 30(6), 871-874.

Carrazza, M. Z., Carrazza, F. R., \& Oga, S. (2000). Clinical and laboratory parameters in dapsone acute intoxication. Carrazza, M Z Carrazza, F R Oga, S, 34(4), 396-401.

Czogała, J., Wardas, W., \& Goniewicz, M. Ł. (2006). Determination of low carboxyhemoglobin blood levels by gas chromatography. Analytica Chimica Acta, 556(2), 295-300. https://doi.org/10.1016/j.aca.2005.09.074

Ehlers, M., Labaze, G., Hanakova, M., McCloskey, D., \& Wilner, G. (2009). Alarming Levels of Carboxyhemoglobin in Banked Blood. Journal of Cardiothoracic and Vascular Anesthesia, 23(3), 336-338. https://doi.org/10.1053/j.jvca.2008.12.006

Evelyn, K. A., \& Malloy, H. T. (1938). Microdetermination of oxyhemoglobin, methemoglobin, and sulfhemoglobin in a single sample of blood. Journal of Biological Chemistry, 126, 655-662.

Krautter, G. R., Chen, P. X., \& Borgerding, M. F. (2015). Consumption patterns and biomarkers of exposure in cigarette smokers switched to Snus, various dissolvable tobacco products, Dual use, or tobacco abstinence. Regulatory Toxicology and Pharmacology, 71(2), 186-197. https://doi.org/10.1016/j.yrtph.2014.12.016

Madany, I. M. (1992). Carboxyhemoglobin levels in blood donors in Bahrain. Science of the Total Environment, The, 116(1-2), 53-58. https://doi.org/10.1016/0048-9697(92)90364-X

Maestrelli, P., El Messlemani, A. H., De Fina, O., Nowicki, Y., Saetta, M., Mapp, C., \& Fabbri, L. M. (2001). Increased expression of heme oxygenase (HO)-1 in alveolar spaces and HO-2 in alveolar walls of smokers. American Journal of Respiratory and Critical Care Medicine, 164(8 I), 1508-1513. https://doi.org/10.1164/ajrccm.164.8.2011083

Mao, Q., Kawaguchi, A. T., Mizobata, S., Motterlini, R., Foresti, R., \& Kitagishi, H. (2021). Sensitive quantification of carbon monoxide in vivo reveals a protective role of circulating hemoglobin in CO intoxication. Communications Biology, 4(1), 1-16. https://doi.org/10.1038/s42003-021-01880-1

Milman, N., \& Pedersen, A. N. (2009). Blood haemoglobin concentrations are higher in smokers and heavy alcohol consumers than in non-smokers and abstainers - Should we adjust the reference range? Annals of Hematology, 88(7), 687-694. https://doi.org/10.1007/s00277-008-0647-9

Rajashekharaiah, V., Koshy, A. A., Koushik, A. K., Kaur, H., Kumari, K., Agrawal, M., Priyanka, Ramya, Khatai, S., Gowda, V., \& Kumar, V. (2012). The efficacy of erythrocytes isolated from blood stored under blood bank conditions. Transfusion and Apheresis Science, 47(3), 359-364. https://doi.org/10.1016/j.transci.2012.06.014

Ramirez, H. B., Alvarez, R. F., Cuadrado, G. R., Gonzalez, C. M., Jerez, F. R., \& Clara, P. C. (2014). Elevated carboxyhemoglobin: Sources of carbon monoxide exposure. Archivos de Bronconeumologia, 50(11), 465-468. https://doi.org/10.1016/j.arbr.2014.09.009

Salles, J. C. (2013). Exposição ao monóxido de carbono: as alterações cardiovasculares no organismo humano. Universidade Federal da Bahia.

Scaff, J. E. R. S., Oliveira, G. G. R., Filho, A. R. A. F., Marques, L. G. R. de A., Rebouças, L. O. V., Madi Filho, S. A., \& Silva Júnior, J. L. R. da. (2020). 
Research, Society and Development, v. 10, n. 10, e294101018859, 2021

(CC BY 4.0) | ISSN 2525-3409 | DOI: http://dx.doi.org/10.33448/rsd-v10i10.18859

Prevalência e fatores relacionados a metahemoglobinemia em indivíduos da atenção básica de Anápolis-Go. Brazilian Journal of Development, 6(7), 4427044280. https://doi.org/10.34117/bjdv6n7-153

Siqueira, M. E. P. B. de, Martins, I., Costa, A. C., Andrade, E. L., Esteves, M. T. C., \& Lima, S. A. (1997). Reference values for carboxyhemoglobin. Journal of Public Health, 31(6), 618-623. https://doi.org/10.22278/2318-2660.2016.v40.n3.a1838

Siqueira, M.E.P.B. de, Vieira, E.P., Brockelmann, C.S.R., Martins, I. (1999). Biomarkers evaluation in tobacco smokers: carboxyhemoglobin, urinary thiocyanate and plasma thiocyanate. Brazj Pharm Sci, 35: 65-72.

Smithline, H. A., Ward, K. R., Chiulli, D. A., Blake, H. C., \& Rivers, E. P. (2003). Whole body oxygen consumption and critical oxygen delivery in response to prolonged and severe carbon monoxide poisoning. Resuscitation, 56(1), 97-104. https://doi.org/10.1016/S0300-9572(02)00272-1

Spada, C., Treitinger, A., \& Souza, M. A. (2006). Prevalência do tabagismo em doadores de sangue da região serrana de Santa Catarina - Brasil. Revista Brasileira de Hematologia e Hemoterapia, 28(1), 19-23. https://doi.org/10.1590/S1516-84842006000100006

Szczepiorkowski, Z. M., \& Dunbar, N. M. (2013). Transfusion guidelines: when to transfuse. Hematology / the Education Program of the American Society of Hematology. American Society of Hematology. Education Program, 2013, 638-644. https://doi.org/10.1182/asheducation-2013.1.638

Uchida, I., Tashiro, C., Koo, Y. H., Mashimo, T., \& Yoshiya, I. (1990). Carboxyhemoglobin and methemoglobin levels in banked blood. Journal of Clinical Anesthesia, 2(2), 86-90. https://doi.org/10.1016/0952-8180(90)90059-C

Westphal, M., Morita, N., Enkhbaatar, P., Murakami, K., Traber, L., \& Traber, D. L. (2003). Carboxyhemoglobin formation following smoke inhalation injury in sheep is interrelated with pulmonary shunt fraction. Biochemical and Biophysical Research Communications, 311(3), 754-758, https://doi.org/10.1016/j.bbrc.2003.10.063 